\title{
Identified SSR Marker Linked to Leaf, Stripe and Steam Rust Resistance Genes in Some High Yield Potential Bread and Durum Wheat varieties
}

\author{
El-Gharbawy Hoda, M. M. and Gad, K. I. M. \\ Wheat Research Department, Field Crops Research Institute, Agricultural Research Center, Giza station.
} Corresponding author: hodaelgharbawy@yahoo.com

\begin{abstract}
This study was conducted to identify SSR markers linked to leaf, stripe and stem rusts resistance genes $L r 34$, $\operatorname{Lr} 19$ and $\operatorname{Lr} 47, \operatorname{Yr} 10$ and $\mathrm{Yr} 15$ and $\mathrm{Sr}$ 2, Sr12, Sr 24, Sr $26 \# 43$ and $\mathrm{Sr} 25$ to be used as markers for identifying the rust resistance genes in seventeen Egyptian bread and durum wheat varieties and two promising lines produced from doubled haploid plants. Bread wheat varieties (Misr 1, Giza 168, Gemmieza 10, Nubaria 1, Sahel 1, Sids 13, Sids 4, Sakha 94, Gemmeiza 11, Giza 171, Gemmeiza 9, Sids 1 and two doubled haploid promising lines DH 2 and DH3) and durum wheat varieties (Bani Suef 5, Bani Suef 6 and Sohag 3). The materials were planted in the two successive growing seasons 2015/2016 and 2016/2017 at El-Giza research station to determine some characters, i. e., No. of kernels/spike, No. of spikes $/ \mathrm{m}^{2}, 1000$-kernel weight(g) and grain yield Ardab/faddan. Moreover, materials were tested to rust diseases in Sakha and Nubaria stations in 2015/2016 and 2016/2017. Significant differences were found among varieties in the two growing seasons, in all characters in this study. DH\#3 promising line recorded the highest value in No. of spikes $/ \mathrm{m}^{2}$ and grain yield ardab/faddan in the two growing seasons. Misr 1, Giza 171, DH\#2 and DH\#3 had no infection of rust reaction in the two growing seasons for the three types of rusts, but Sids 13 and Nubaria 1 were 5MS (moderate susceptible) for Yr rust and 10 MS for $\mathrm{Lr}$ rust. However, $\mathrm{Sr}$ rust reaction zero no infection in all genotypes. $\mathrm{Yr} 10$ and $\mathrm{Yr} 15$ stripe rust resistant gene used in this study, positive molecular marker Linked to $\mathrm{Yr} 10$ detected in Misr1, Sids 1and DH3, while $\operatorname{Yr} 15$ was detected in Misr 1, Giza 168, Sahel 1, Sids 4, Sids 1, Bani Suef 5, Bani Seif 6, DH\#2 and DH\#3. Lr 34 leaf rust gene was found in Sids 13, Sakha 94 and DH\#3, while Lr 47 gene was detected in Misr 1, DH\#2 and DH\#3, but $\operatorname{Lr} 19$ was detected in any genotype. Sr 2 durable resistant stem rust gene was detected in all genotypes expect Sids 1, moreover $\mathrm{Sr} 26 \# 43$ detected in all genotypes too expect Sids 4 variety. $\mathrm{Sr} 12$ gene was detected in Misr 1, Giza 171, Gemmeiza 9 and DH\# 3. All genotypes had no $\operatorname{Sr} 24$, While $\operatorname{Sr} 25$ resistance gene was detected in Misr 1, Giza 171 and DH\#3 genotypes. Dedication of more than one gene in any variety is useful for durable resistance. Seven rust genes were detected in Misr 1 for the three rusts and eight genes were found in promising line DH\#3, which caused resistant to rust. So, Misr 1 and DH\#3 are considered as promising bread wheat high yielding genotypes and resistant to rust diseases can which be used in breeding program, as pre breeding in hybridization program.
\end{abstract}

Keywords: bread, durum, Wheat, resistance gene, SSR marker, yield, rust diseases, rust reaction.

\section{Introduction}

Wheat (Triticum aestivum L.) is one of the most important crops in the world. It is the staple food of 43 countries, and about one-third of the world's population depends on wheat for food (Encyclopedia Britannica online). Increasing grain yield of wheat crop is considered one of the most important national goals in Egypt to face the decreased self-sufficient which result from rapid increasing of population. Only, $65 \%$ of self-sufficient from wheat were produced in 2016/2017 season. The total production was estimated by 8.757 million tons resulted from 2.92 million Faddan (The Agricultural Economic and Statistics Department, Ministry of Agriculture, 2017). Hard efforts have been done to increasing the total wheat production. This increasing could be achieved by vertical or horizontal expansion. Leaf rust (brown rust), stripe rust (yellow rust), and stem rust (black rust) for wheat are caused by Puccinia triticina Eriks., Puccinia striformis, and Puccinia graminis $f$. sp. tritici respectively. Rusts are the most important plant diseases that threaten wheat vertical expansion in Egypt under severe infection, rust pathogen can destroy the entire susceptible wheat crop and make big economic losses (Marsalis and Goldberg, 2006). The most common rust is leaf rust, it occurs on the leaf blades, and leaf sheaths can also be infected under favorable conditions, with high inoculation densities, and extremely susceptible cultivars. Losses of grain yield can be increased to $30 \%$ or more. Stem rust is also known as black rust due to the abundant production of shiny black teliospores. Stem rust is favored by humid warmer condition. It may decrease grain yield by $50 \%$, these losses can be achieved to $100 \%$ with susceptible cultivars. Stripe or yellow rust is principally occurred under low temperature conditions with temperature degree ranged from 2 to $15^{\circ} \mathrm{C}$. Losses under extreme situations can be achieved to $100 \%$ losses (Roelfs et al 1992). Plant breeders work to develop cultivars with genetic resistance against rust disease. Breeding for disease resistance is the most effective method to crop protection. Selection of cultivars with singlegene resistance has short time resistance as results to the ability of pathogen to produce single step mutations. In addition, it is difficult to detect a single gene of interest within a complex background of other 
resistance genes. Hence, using combinations of resistance genes is the best method for achieving to adequate genetic control of rust diseases for wheat (Roelfs, 1989). Consequently, plant pathologists and plant breeders have a priority to develop resistance varieties with high-yielding capacity through pyramiding effective resistance genes with durable resistance. This gene pyramiding strategy, also known as multigenic resistance. It has been used to increase the durability of resistance. Using combinations of genes has been suggested as the best method for genetic control of rust (Roelfs, 1988 and Savitha et al., 2016). Using selection application of molecular techniques and Marker-Assisted (MAS) can help in breeding program to reduce the period of time and help in pyramiding resistance genes into single cultivar for durable resistance in segregating populations, Qi et al. (2015) and Chhuneja et al. (2011). Resistance to rust can be divided into two categories, qualitative and quantitative resistance, Qi et al. (2015).

The objective of this study was to evaluate the selected genotypes for their resistance to rust diseases and identify genes linked to this resistance by using SSR marker.

\section{Materials and Methods}

A field experiment was carried out at the Agricultural Research Center at El-Giza, Egypt, during the two successive seasons 2015/2016 and 2016/2017. fourteen bread (Triticum aestivum L.) and three durum wheat (Triticum durum var. durum) genotypes were used in the present study. These genotypes were selected on the basis of their genetic diversity. The pedigree of the selected genotypes is presented in Table (1). Each season, three experiments were conducted at El-Giza, Sakha, and Nubaria Agricultural Stations, Agricultural Research Center, Egypt. Seventeen cultivars were arranged in a randomized complete block design (RCBD). The plot area was $6.3 \mathrm{~m}^{2}$ (6 rows, $3.5 \mathrm{~m}$ long and $30 \mathrm{~cm}$ apart). All recommended cultural practices were adopted. Sakha and EL-Nubaria are hot spot regions; they are subjected to severe attack of yellow, leaf, and stem rusts.

Table 1. The Name, Pedigree and Origin of the Seventeen Bread and Durum Wheat Genotypes.

\begin{tabular}{|c|c|c|}
\hline Ser & Varieties & Pedigree \\
\hline \multirow{2}{*}{1} & \multirow{2}{*}{ Misr1 } & OASIS/SKAUZ//4*BCN/3/2*PASTOR \\
\hline & & CMSS00Y01881T-050M-030Y-030M-030WGY-33M-0Y-0S \\
\hline \multirow{2}{*}{2} & \multirow{2}{*}{ Giza168 } & MRL/BUC//SERI \\
\hline & & CM93046-8M-0Y-0M-2Y-0B-0GZ \\
\hline \multirow{2}{*}{3} & \multirow{2}{*}{ Gem 10} & MAYA74/0N//160-147/3/BB/GLL/4/CHAT/5/CROW \\
\hline & & GM5820-3GM-1GM-2GM-0GM \\
\hline 4 & Nubaria 1 & OASIS/5*BOR95/4/CNDO/R143//ENTE/MEX175/3/CNDO/R143 \\
\hline \multirow{2}{*}{5} & \multirow{2}{*}{ Sahel 1} & N.S.732/PIMA//VEE \\
\hline & & SD735-4SD-1SD-1SD-0SD \\
\hline \multirow{2}{*}{6} & \multirow{2}{*}{ Sids 13} & KAUZ//TSI/TSI/SNB \\
\hline & & ICW94-0375-4AP-2AP-030AP-0APS-3AP-0APS-050AP-0AP-SD \\
\hline \multirow{2}{*}{7} & \multirow{2}{*}{ Sids 4} & MAYA/MON//CMH74A.592/3/GIZA157*2 \\
\hline & & SD10001-2SD-3SD-2SD-0SD \\
\hline \multirow{2}{*}{8} & \multirow{2}{*}{ Sakha 94} & OPATA/RAYON//KAUZ \\
\hline & & CMBW90Y3180-0TOPM-3Y-010M-010M-010Y-10M-015Y-0Y-0AP-0S \\
\hline \multirow{2}{*}{9} & \multirow{2}{*}{ Gemmeiza 11} & B0W/KVZ//7C/SERI82/3/GIZA168/SAKHA61 \\
\hline & & GM7892-2GM-1GM-2GM-1GM-0GM \\
\hline \multirow{2}{*}{10} & \multirow{2}{*}{ Giza 171} & Sakha93/Gemmeiza9 \\
\hline & & $\mathrm{Gz} 2003-101-1 \mathrm{Gz}-4 \mathrm{Gz}-1 \mathrm{Gz}-2 \mathrm{Gz}-0 \mathrm{Gz}$ \\
\hline \multirow{2}{*}{11} & \multirow{2}{*}{ Gemmeiza 9} & ALD/HUAC//CMH74A.630/SX \\
\hline & & GM4583-5GM-1GM-0GM \\
\hline \multirow{2}{*}{12} & \multirow{2}{*}{ Sids 1} & HD2172/PAVON//1158.57/MAYA74 \\
\hline & & SD46-4SD-2SD-1SD-0SD \\
\hline \multirow{2}{*}{13} & \multirow{2}{*}{ Beni Suef 5} & DIPPERZ/BUSHEN3 \\
\hline & & CDSS92B128-1M-0Y-0M-0Y-3B-0Y-0SD \\
\hline \multirow{2}{*}{14} & \multirow{2}{*}{ Beni Suef 6} & BOOMER-21/BUSCA-3 \\
\hline & & CDSS95Y001185-8Y-0M-0Y-0B-1Y-0B-0SD \\
\hline \multirow{2}{*}{15} & \multirow{2}{*}{ Sohag 3} & MEXI/MGHA/51792//DURUM6 \\
\hline & & CD21831-25H-1SH-0SH \\
\hline \multirow{2}{*}{16} & \multirow{2}{*}{ DH\# 2} & SAKHA94/MISR1 \\
\hline & & GZ2008-06DH2 \\
\hline \multirow{2}{*}{17} & $\mathrm{DH \#} 3$ & SAKHA94/MISR1 \\
\hline & DH\# 3 & GZ2008-06DH3 \\
\hline
\end{tabular}


Giza experiments were conducted to evaluate yield and yield components. Thus, number of fertile spikes/m2 was counted from each plot just before harvesting. In addition, five randomly selected main spikes were picked, threshed, and their kernels were counted. Their average was recorded to indicate the No. of kernels/spike. Moreover, ten plants were randomly selected from each plot. At harvest, six rows were harvested, weighed and threshed; and their grain yields were weighed and adjusted to arddab/faddan to indicate the grain yield. Likewise, a random sample of 1000 kernels, taken from each plot was hand counted and weighed to indicate the kernel weight. Statistical analysis of variance was made to determine the effect of seasons, genotypes and their interaction using Statistical Package for the Social Sciences (SPSS).

\section{DNA Extraction and PCR Protocol}

Total cellular DNA of parents was isolated by using Cetyl Trimethyle Ammonium Bromide (CTAB) method, Dellaporta et al. (1983). PCR reactions were carried out from the purified genomic DNA with the total reaction mixture of $25 \mu \mathrm{L}, 1 \mu \mathrm{L}$ of $10 \mathrm{mM} \mathrm{MgCl}_{2}$, $1 \mu \mathrm{L}$ of $2.5 \mathrm{mM}$ dNTPs, $0.5 \mu \mathrm{L}$ each of forward and reverse primers ( 5 pmoles), $0.25 \mu \mathrm{L}$ of $3 \mathrm{U}$ Taq DNA polymerase and $12.75 \mu \mathrm{L}$ from sterile distilled water. Total reaction mixture was subjected to PCR (Biorad PTC-200) amplification with the cycling parameters according to each gene presented in Table (2).

PCR products were visualized on $4 \%$ superfine agarose gel stained with Ethidium Bromide and run in $1 \mathrm{X}$ TBE buffer. Low range ruler with a ladder range of 100-1,000 bp was used as a standard molecular marker with known weights as control

Table 2. Markers Name, Sequence Primers and Amplified Cycles Parameters of SSR Markers Linked To Rust Resistance Genes.

\begin{tabular}{|c|c|c|}
\hline Genes & Marker Sequence & PCR program \\
\hline Lr34 & $\begin{array}{l}\text { F: 5'GTTGGTTAAGACTGGTGATGG } \\
\text { R: 5'TGCTTGCTATTGCTGAATAG }\end{array}$ & $\begin{array}{l}94^{\circ} \mathrm{C} \text { for } 4 \mathrm{~min}, 35 \text { cycles }\left(94^{\circ} \mathrm{C} \text { for } 1 \mathrm{~min}, 55^{\circ} \mathrm{C} \text { for }\right. \\
\left.1 \mathrm{~min} \text { and } 72^{\circ} \mathrm{C} \text { for } 1 \mathrm{~min}\right) \text { and } 72^{\circ} \mathrm{C} \text { for } 6 \mathrm{~min}\end{array}$ \\
\hline Lr 47 & $\begin{array}{l}\text { F: 5'GCTGATGACCCTGACGG } \\
\text { R: 5'TCTTCATGCCCGGTCGGGT }\end{array}$ & $\begin{array}{l}94^{\circ} \mathrm{C} \text { for } 4 \mathrm{~min}, 35 \mathrm{cycles}\left(94^{\circ} \mathrm{C} \text { for } 1 \mathrm{~min}, 55^{\circ} \mathrm{C} \text { for }\right. \\
\left.1 \mathrm{~min} \text { and } 72^{\circ} \mathrm{C} \text { for } 2 \mathrm{~min}\right) \text { and } 72^{\circ} \mathrm{C} \text { for } 10 \mathrm{~min}\end{array}$ \\
\hline Yr 10 & $\begin{array}{l}\text { F: 5'TCAAAGACATCAAGAGCCGC } \\
\text { R: 5'TGGCCTACATGAACTCTGGAT }\end{array}$ & $\begin{array}{l}94^{\circ} \mathrm{C} \text { for } 3 \mathrm{~min}, 30 \text { cycles }\left(94^{\circ} \mathrm{C} \text { for } 1 \mathrm{~min}, 64^{\circ} \mathrm{C} \text { for }\right. \\
\left.45 \mathrm{sec} \text { and } 72^{\circ} \mathrm{C} \text { for } 1 \mathrm{~min}\right) \text { and } 72^{\circ} \mathrm{C} \text { for } 5 \mathrm{~min}\end{array}$ \\
\hline Yr 15 & $\begin{array}{l}\text { F: 5'ATTGGACGGACAGATGCT TT } \\
\text { R: 5' AGCAGTGAGGAAGGGGATC } \\
\end{array}$ & $\begin{array}{l}94^{\circ} \mathrm{C} \text { for } 3 \mathrm{~min}, 45 \text { cycles }\left(94^{\circ} \mathrm{C} \text { for } 1 \mathrm{~min}, 58^{\circ} \mathrm{C} \text { for } 1 \mathrm{~min}\right. \\
\left.20 \mathrm{sec} \text { and } 72^{\circ} \mathrm{C} \text { for } 2 \mathrm{~min}\right) \text { and } 72^{\circ} \mathrm{C} \text { for } 10 \mathrm{~min}\end{array}$ \\
\hline Sr2 & $\begin{array}{l}\text { R: 5'AAG GCGAAT CAA ACG GAA TA } \\
\text { F: 5' GTT GCT TTAGGG GAA AAG CC }\end{array}$ & $\begin{array}{l}95^{\circ} \mathrm{C} \text { for } 5 \mathrm{~min}, 35 \text { cycles }\left(94^{\circ} \mathrm{C} \text { for } 1 \mathrm{~min}, 60^{\circ} \mathrm{C} \text { for }\right. \\
\left.45 \mathrm{sec} \text { and } 72^{\circ} \mathrm{C} \text { for } 2 \mathrm{~min}\right), 72^{\circ} \mathrm{C} \text { for } 7 \mathrm{~min} \text { and } 4^{\circ} \mathrm{C} \\
\text { for forever }\end{array}$ \\
\hline Sr24\#12 & $\begin{array}{l}\text { F5'- CAC CCG TGA CAT GCT CGT A } \\
\text { R5'-AACAGGAAATGAGCA ACG ATG T }\end{array}$ & $\begin{array}{l}94^{\circ} \mathrm{C}, 5 \mathrm{~min}, 7 \mathrm{cycles}, 1^{\circ} \mathrm{C} \text { each cycle: } 92^{\circ} \mathrm{C} 30 \mathrm{sec} \text {, } \\
62^{\circ} \mathrm{C} 30 \mathrm{sec}, 72^{\circ} \mathrm{C} 30 \mathrm{sec}, 30 \text { cycles } 92^{\circ} \mathrm{C} 30 \mathrm{sec} \text {, } \\
59^{\circ} \mathrm{C} 30 \mathrm{sec}, 72^{\circ} \mathrm{C} 30 \mathrm{sec} \text { and } 72^{\circ} \mathrm{C} 10 \mathrm{~min}\end{array}$ \\
\hline Sr26 & $\begin{array}{l}\text { F5'- AAT CGT CCA CAT TGG CTT CT } \\
\text { R5'- CGC AAC AAA ATC ATG CAC TA }\end{array}$ & $\begin{array}{l}94^{\circ} \mathrm{C}, 3 \mathrm{~min}, 35 \mathrm{cycles}\left(94^{\circ} \mathrm{C} 60 \mathrm{sec}, 60^{\circ} \mathrm{C} 60 \mathrm{sec},\right. \\
\left.72^{\circ} \mathrm{C} 120 \mathrm{sec}\right) \text {, and } 72^{\circ} \mathrm{C} 10 \mathrm{~min}\end{array}$ \\
\hline $\begin{array}{l}\text { Sr 25\# } \\
\text { Lr19 }\end{array}$ & $\begin{array}{l}\text { F 5'- CAT CCT TGG GGA CCT C } \\
\text { R 5'- CCA GCT CGC ATA CAT CCA }\end{array}$ & $\begin{array}{l}94^{\circ} \mathrm{C} 4 \mathrm{~min},\left(35 \text { cycles } 94^{\circ} \mathrm{C} 45 \mathrm{sec}, 50^{\circ} \mathrm{C} 30 \mathrm{sec}\right. \\
\left.\text { and } 72^{\circ} \mathrm{C} 45 \mathrm{sec}\right) \text { and } 72^{\circ} \mathrm{C} 7 \mathrm{~min}\end{array}$ \\
\hline
\end{tabular}

\section{Results and Discussion}

The combined analysis of variance for data obtained from El-Giza location during 2015/2016 and $2016 / 2017$ revealed insignificant effect of seasons, and the interaction between season and all studied characters. Therefore, data in table (3) represent the results of combined analysis for yield and yield components at El-Giza station.

Data recorded significant differences among wheat cultivars for grain yield. Results show that line $\mathrm{DH} \# 3$ had the highest value of grain yield without significant different from DH\#2, and Giza 171. Data in (Table 3) recorded the superiority of Sids 4 in kernels weight. Meanwhile, promising line DH\#3 had the highest number of spikes per square meter without significant difference from DH\#2 Recorded data showed that highest No. of kernels/spike from Sids 4 without significant difference from DH\#2 and DH\#3, Giza 171, Gemmiza 11, Misr 1, and Sids 1. Performance of wheat genotypes remains a key criterion for screening breeding materials based on their yield parameter, and yield components Peltonen-Sainio (2007) and Mahmoud and Ahmed (2005). 
Table 3. Mean of grain yield (ard./fad.), 1000-kernel weight (g), No. of spikes $/ \mathrm{m}^{2}$, and No. of kernels/spike in two growing seasons 2015/2016 and 2016/2017.

\begin{tabular}{|c|c|c|c|c|}
\hline Varieties & $\begin{array}{c}\text { Grain yield } \\
\text { Ard./fad. }\end{array}$ & $\begin{array}{c}\text { 1000kernel } \\
\text { weight/g }\end{array}$ & $\begin{array}{c}\text { No. of } \\
\text { spike/m² }\end{array}$ & $\begin{array}{c}\text { No. of kernels } \\
\text { /spike } \\
\end{array}$ \\
\hline Misr1 & 26.32 & 48.98 & 443.33 & 70.50 \\
\hline Giza168 & 26.32 & 45.00 & 447.50 & 69.67 \\
\hline Gem 10 & 24.91 & 47.67 & 373.00 & 59.00 \\
\hline Nubaria 1 & 24.59 & 44.88 & 353.50 & 54.50 \\
\hline Sahel 1 & 25.04 & 42.17 & 374.17 & 58.17 \\
\hline Sids 13 & 24.30 & 40.48 & 343.67 & 56.83 \\
\hline Sids 4 & 18.89 & 61.58 & 157.00 & 76.17 \\
\hline Sakha 94 & 26.76 & 41.33 & 434.34 & 63.67 \\
\hline Gemmeiza 11 & 27.59 & 51.52 & 430.33 & 72.33 \\
\hline Giza 171 & 27.92 & 46.53 & 469.50 & 73.00 \\
\hline Gemmeiza 9 & 26.39 & 47.70 & 431.50 & 62.17 \\
\hline Sids 1 & 26.72 & 51.93 & 469.50 & 70.00 \\
\hline Beni Suef 5 & 25.75 & 56.00 & 426.83 & 67.00 \\
\hline Beni Suef 6 & 25.78 & 51.28 & 395.67 & 65.67 \\
\hline Sohag 3 & 24.95 & 51.60 & 333.83 & 58.50 \\
\hline DH\#2 & 28.08 & 50.97 & 494.67 & 73.83 \\
\hline DH\#3 & 28.37 & 51.67 & 503.50 & 73.67 \\
\hline Mean & 25.81 & 48.90 & 443.38 & 66.16 \\
\hline LSD 5\% & 0.7 & 3.35 & 18.62 & 6.31 \\
\hline
\end{tabular}

Final rust severity: To evaluate seventeen released wheat cultivars for their slow rusting resistance to leaf, stem, and yellow rusts two field experiments were conducted at Sakha and Nubaria stations during 2015/2016 and 2016/2017 growing seasons. The highest types of genotypes infection for yellow rust at Nubaria and Sakha during the two growing seasons are presented in table (4). Moderate resistance was detected for Giza 168, Gemmiza 10, Sahel 1, Sids 4, and Sohag 3. While, no yellow rust infection was detected on Misr 1, Sakha 94, Gemmeiza 11, Giza 171, Gemmeiza 9, Bani Suef 5, Bani Suef 6, DH\# 2 and DH\# 3.

Table 4. The Highest Types of Genotypes Infections for Yellow Rust at Nubaria and Sakha During The Two Growing Seasons .

\begin{tabular}{ccccc}
\hline Ser & Varieties & Nubaria & Sakha & Yr \\
\hline 1 & Misr1 & 0 & 0 & 0 \\
\hline 2 & Giza168 & $\mathrm{R}$ & $\mathrm{TrMr}$ & $\mathrm{Tr} \mathrm{Mr}$ \\
\hline 3 & Gem 10 & 0 & $\mathrm{Mr}$ & $5 \mathrm{Mr}$ \\
\hline 4 & Nubaria 1 & TrMs & $5 \mathrm{Ms}$ & $5 \mathrm{Ms}$ \\
\hline 5 & Sahel 1 & $\mathrm{R}$ & $\mathrm{TrMr}$ & $\mathrm{Tr} \mathrm{MR}$ \\
\hline 6 & Sids 13 & TrMs & $5 \mathrm{Ms}$ & $5 \mathrm{Ms}$ \\
\hline 7 & Sids 4 & $5 \mathrm{Mr}$ & $10 \mathrm{Mr}$ & $10 \mathrm{Mr}$ \\
\hline 8 & Sakha 94 & 0 & 0 & 0 \\
\hline 9 & Gemmeiza 11 & 0 & 0 & 0 \\
\hline 10 & Giza 171 & 0 & 0 & 0 \\
\hline 11 & Gemmeiza 9 & 0 & 0 & 0 \\
\hline 12 & Sids 1 & $10 \mathrm{Mr}$ & $5 \mathrm{Ms}$ & $5 \mathrm{Ms}$ \\
\hline 13 & Beni Suef 5 & 0 & 0 & 0 \\
\hline 14 & Beni Suef 6 & 0 & 0 & 0 \\
\hline 15 & Sohag 3 & $\mathrm{TrMr}$ & $5 \mathrm{Mr}$ & $5 \mathrm{Mr}$ \\
\hline 16 & DH\# 2 & 0 & 0 & 0 \\
\hline 17 & DH\# 3 & 0 & 0 & 0 \\
\hline
\end{tabular}

These fourteen cultivars could be considered as resistant cultivars. On the other hand, Nubaria 1 Sids 13, and Sids 1 were detected as susceptible cultivars.
Data in table (5) present the highest type of leaf rust infection at Nubaria and Sakha during the two growing seasons show that Misr 1, Giza 171, DH\# 2 
and DH\# 3 were resistant cultivars. Moreover, Giza 168, Gemmiza 10, Sahel 1, Sids 4, Sakha 94, Gemmiza 11, Gemmiza 9, Beni Suef 5, Beni Suef 6, and Sohag 3 had moderate resistance. On the other hand, Nubaria 1, Sids 13, and Sids 1 were detected as susceptible cultivars.

Table 5. Highest Types of Genotypes Infections for Leaf Rust at Nubaria And Sakha During The Two Growing Seasons .

\begin{tabular}{|c|c|c|c|c|}
\hline Ser & Varieties & Nubaria & Sakha & $\mathbf{L r}$ \\
\hline 1 & Misr1 & 0 & 0 & 0 \\
\hline 2 & Giza168 & $5 \mathrm{Mr}$ & $\mathrm{R}$ & $5 \mathrm{Mr}$ \\
\hline 3 & Gem 10 & $10 \mathrm{Mr}$ & $5 \mathrm{Mr}$ & $10 \mathrm{Mr}$ \\
\hline 4 & Nubaria 1 & $10 \mathrm{Ms}$ & $5 \mathrm{Ms}$ & $10 \mathrm{Ms}$ \\
\hline 5 & Sahel 1 & $10 \mathrm{Mr}$ & $\mathrm{TrMr}$ & $10 \mathrm{Mr}$ \\
\hline 6 & Sids 13 & $10 \mathrm{Ms}$ & $5 \mathrm{Ms}$ & $10 \mathrm{Ms}$ \\
\hline 7 & Sids 4 & $5 \mathrm{Mr}$ & $\mathrm{R}$ & $5 \mathrm{Mr}$ \\
\hline 8 & Sakha 94 & $5 \mathrm{Mr}$ & 0 & $5 \mathrm{MR}$ \\
\hline 9 & Gemmeiza 11 & $10 \mathrm{Mr}$ & 0 & $10 \mathrm{Mr}$ \\
\hline 10 & Giza 171 & 0 & 0 & 0 \\
\hline 11 & Gemmeiza 9 & $\mathrm{TrMr}$ & 0 & $\mathrm{TrMr}$ \\
\hline 12 & Sids 1 & $5 \mathrm{Ms}$ & $5 \mathrm{Ms}$ & $5 \mathrm{Ms}$ \\
\hline 13 & Beni Suef 5 & $5 \mathrm{Mr}$ & $\mathrm{R}$ & $5 \mathrm{Mr}$ \\
\hline 14 & Beni Suef 6 & $10 \mathrm{Mr}$ & $\mathrm{R}$ & $10 \mathrm{Mr}$ \\
\hline 15 & Sohag 3 & $10 \mathrm{Mr}$ & $5 \mathrm{Mr}$ & $10 \mathrm{Mr}$ \\
\hline 16 & DH\# 2 & 0 & 0 & 0 \\
\hline 17 & DH\# 3 & 0 & 0 & 0 \\
\hline
\end{tabular}

Obtained show results in table (6) that all studied cultivars had zero type reaction for stem rust disease.

Eight linked specific primers to rust disease were used in this study to identified resistance genes in the seventeen genotypes under study.

Fig (1) showed the present resistance gene ( $\operatorname{Lr} 34)$ in all studied cultivars. Adult plant resistance gene Lr34 may not provide adequate resistance under high disease severity. When it is present alone, it could be contributed as resistance. Leaf tip necrosis (Ltn), a morphological character, showed linkage between Lr34 and Yr18.Thus, it was suggested to be utilized, in some environments, as a morphological marker for wheat lines which carry these genes (Singh et al., 2003).

Table 6. Highest Types of Genotypes Infections for Stem Rust at Nubaria And Sakha During The Two Growing Seasons

\begin{tabular}{|c|c|c|c|c|}
\hline Ser & Varieties & Nubaria & Sakha & $\mathrm{Sr}$ \\
\hline 1 & Misr1 & 0 & 0 & 0 \\
\hline 2 & Giza168 & 0 & 0 & 0 \\
\hline 3 & Gem 10 & 0 & 0 & 0 \\
\hline 4 & Mnubaria 1 & $5 \mathrm{Mr}$ & 0 & $5 \mathrm{Mr}$ \\
\hline 5 & Sahel 1 & 0 & 0 & 0 \\
\hline 6 & Sids 13 & 0 & 0 & 0 \\
\hline 7 & Sids 4 & 0 & 0 & 0 \\
\hline 8 & Sakha 94 & 0 & 0 & 0 \\
\hline 9 & Gemmeiza 11 & 0 & 0 & 0 \\
\hline 10 & Giza 171 & 0 & 0 & 0 \\
\hline 11 & Gemmeiza 9 & 0 & 0 & 0 \\
\hline 12 & Sids 1 & 0 & 0 & 0 \\
\hline 13 & Beni Suef 5 & 0 & 0 & 0 \\
\hline 14 & Beni Suef 6 & 0 & 0 & 0 \\
\hline 15 & Sohag 3 & 0 & 0 & 0 \\
\hline 16 & DH\# 2 & 0 & 0 & 0 \\
\hline 17 & DH\# 3 & 0 & 0 & 0 \\
\hline
\end{tabular}


Lr 34

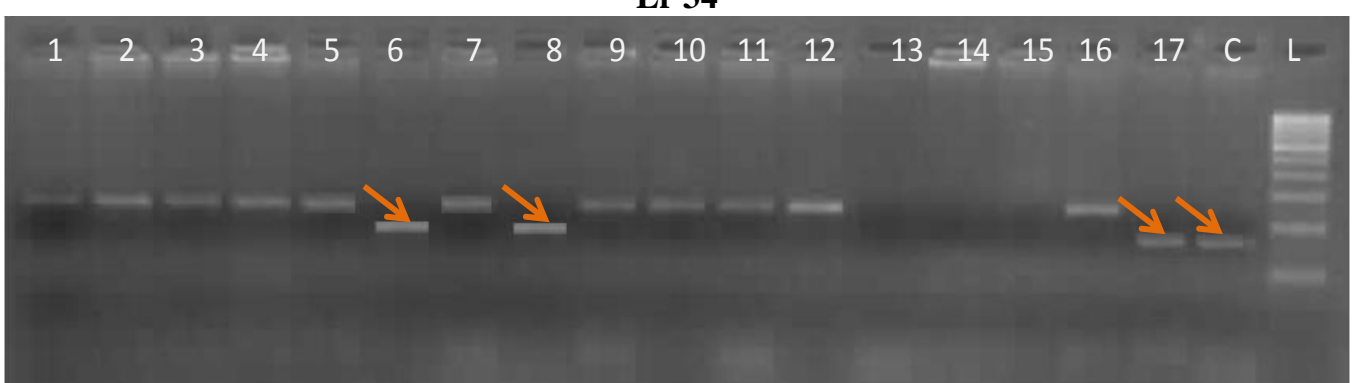

Figure (1): Lr 34 gene in the seventeen cultivars Misr 1; 2. Giza 168; 3. Gemmeiza 10; 4. Nobaria 1; 5. Sahel 1; 6. Sids 13; 7. Sids 4; 8. Sakha 94; 9. Gemmeiza 11; 10. Giza 171; 11. Gemmeiza 9; 12. Sids 1; 13. Bani Sewif 5; 14. Bani Sewif 6; 15. Sohag 3; 16. DH 4; 17. DH 5 ; +C. Positive Control; -C. Negative Control; L.Ladder

fig (2) presented that, the leaf rust resistance gene Lr47 in the seventeen varieties, which confers resistance to a wide spectrum of leaf rust strains. This gene was transferred from chromosome $7 \mathrm{~S}$ of Triticum speltoides to chromosome 7A of Triticum aestivum (Helguera et al. 2000).

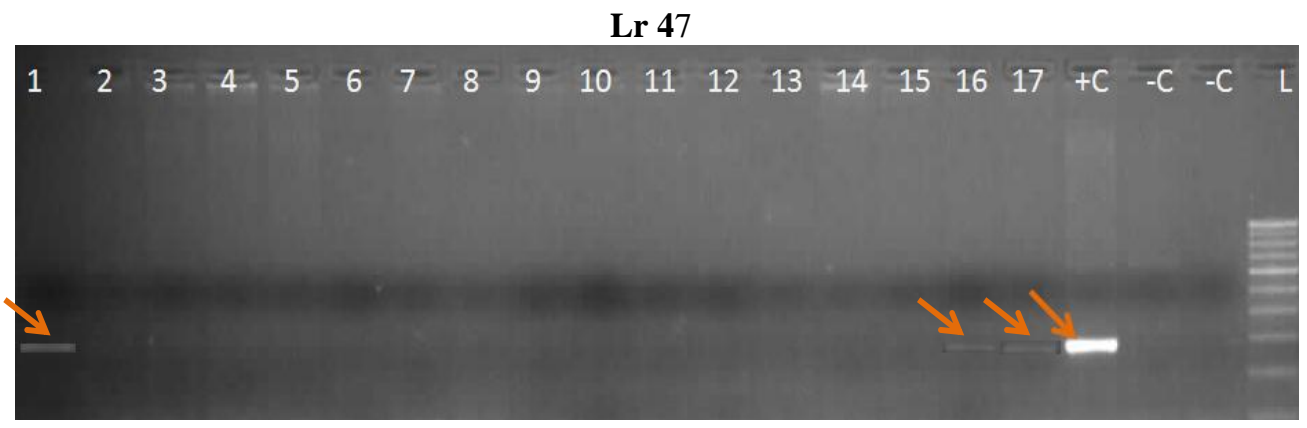

Figure (2): Lr 47 gene in seventeen cultivars 1. Misr 1; 2. Giza 168; 3. Gemmeiza 10; 4. Nobaria 1; 5. Sahel 1; 6. Sids 13; 7. Sids 4; 8. Sakha 94; 9. Gemmeiza 11; 10. Giza 171; 11. Gemmeiza 9; 12. Sids 1; 13. Bani Sewif 5; 14. Bani Sewif 6; 15. Sohag 3; 16. DH 4; 17. DH 5 ; +C. Positive Control; -C. Negative Control; L.Ladder

Yrl0 is one of the catalogued seedling resistance genes fig (3), has been assigned to chromosome $1 \mathrm{~B}$ on the basis of its linkage with $\mathrm{Rg} 1$ gene controlling brown glum color (Metzger and
Silbaugh, 1970) and a second gene, YrMoro, has tentatively been assigned to Chromosome 4B (Chen et al., 1995).

\section{Yr10}

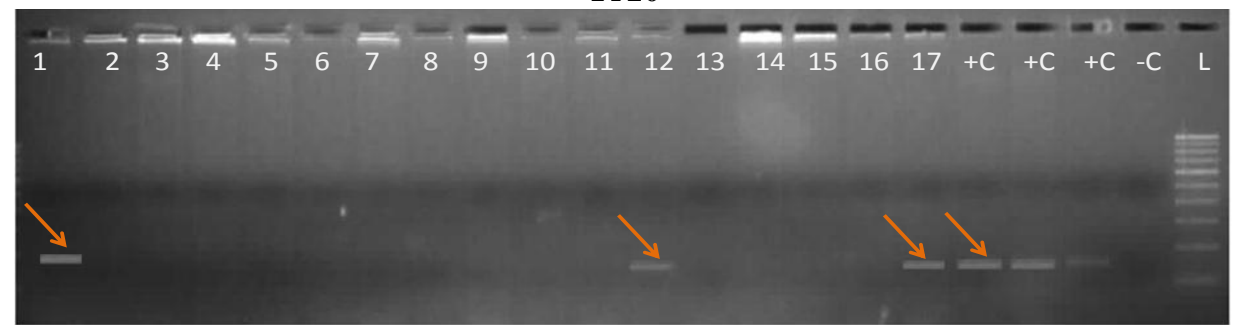

Figure (3): Yr 10 gene in seventeen varieties 1 . Misr 1; 2. Giza 168; 3. Gemmeiza 10; 4. Nobaria 1; 5. Sahel 1; 6. Sids 13; 7. Sids 4; 8. Sakha 94; 9. Gemmeiza 11; 10. Giza 171; 11. Gemmeiza 9; 12. Sids 1; 13. Bani Sewif 5; 14. Bani Sewif 6; 15. Sohag 3; 16. DH 4; 17. DH 5 ; +C. Positive Control; -C. Negative Control; L.Ladder $\operatorname{Yr} 15$ gene was showed in adult plant resistance to the stripe rust races figure (4). 


\section{Yr15}

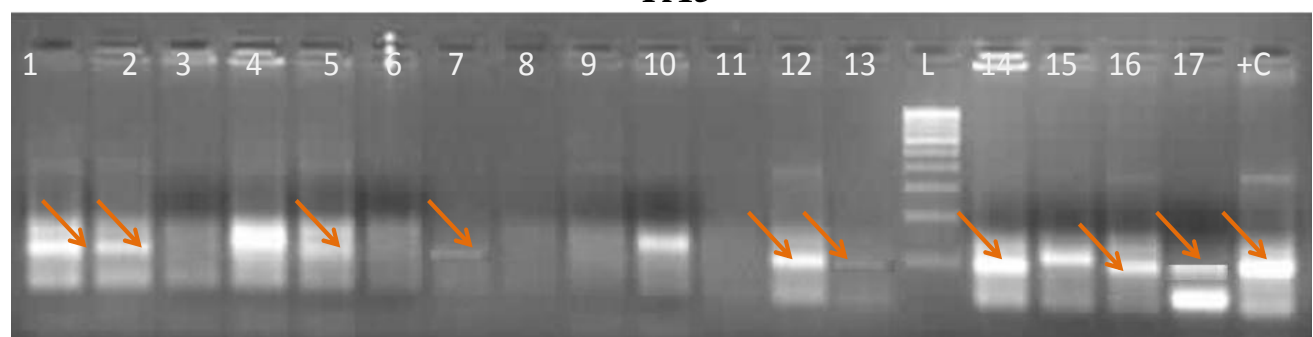

Figure (4): Yr 15 gene in seventeen cultivars 1 . Misr 1; 2. Giza 168; 3. Gemmeiza 10; 4. Nobaria 1; 5. Sahel 1; 6. Sids 13; 7. Sids 4; 8. Sakha 94; 9. Gemmeiza 11; 10. Giza 171; 11. Gemmeiza 9; 12. Sids 1; 13. Bani Sewif

5; 14. Bani Sewif 6; 15. Sohag 3; 16. DH 4; 17. DH 5 ; +C. Positive Control; -C. Negative Control; L.Ladder

$\mathrm{Sr} 2$ is located on the short arm of chromosome 3B and confers partial resistance only in the homozygous state (recessive resistance gene) fig (5).
It was originally transferred from Yaroslavl emmer wheat into hexaploid wheat, Singh (2010).

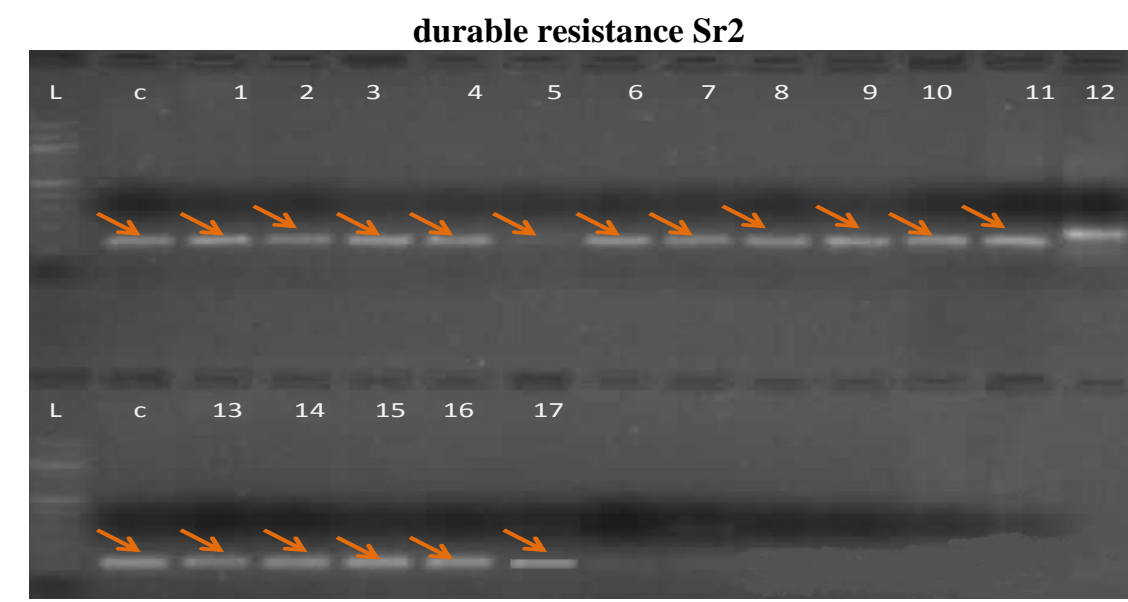

Figure (5): SR 2 gene in seventeen cultivars 1. Misr 1; 2. Giza 168; 3. Gemmeiza 10; 4. Nobaria 1; 5. Sahel 1; 6. Sids 13; 7. Sids 4; 8. Sakha 94; 9. Gemmeiza 11; 10. Giza 171; 11. Gemmeiza 9; 12. Sids 1; 13. Bani Sewif 5; 14. Bani Sewif 6; 15. Sohag 3; 16. DH 4; 17. DH 5 ; +C. Positive Control; -C. Negative Control; L.Ladder

Fig. (6) showed that, $S r 24$ which offers resistance to most races of stem rust, also, STS Sr24\#12 is a dominant marker that amplifies a single 500-bp band linked to Sr24 in reference line Agent (Rouse et al., 2014).

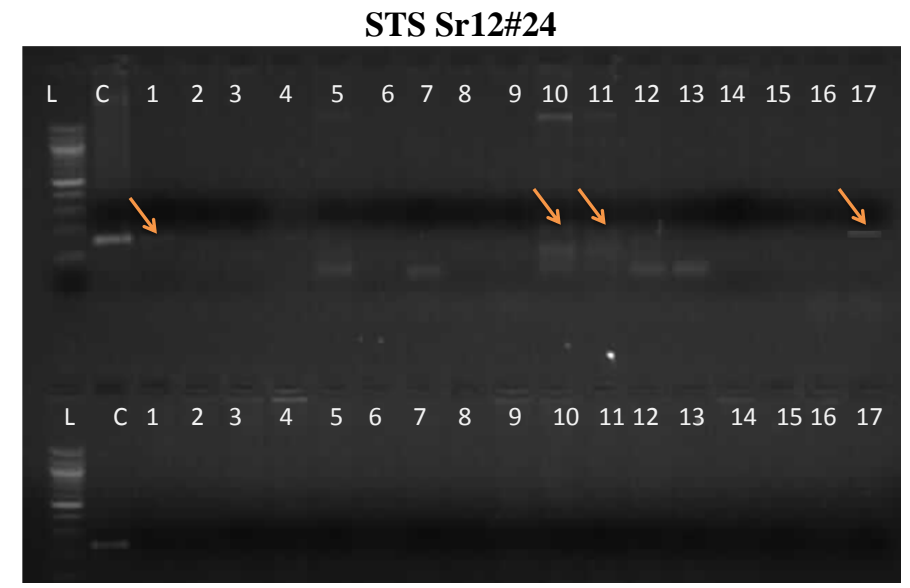

Figure (6): Sr12\#24 genes in seventeen cultivars . Misr 1; 2. Giza 168; 3. Gemmeiza 10; 4. Nobaria 1; 5. Sahel 1; 6. Sids 13; 7. Sids 4; 8. Sakha 94; 9. Gemmeiza 11; 10. Giza 171; 11. Gemmeiza 9; 12. Sids 1; 13. Bani Sewif 5; 14. Bani Sewif 6; 15. Sohag 3; 16. DH 4; 17. DH 5 ; +C. Positive Control; -C. Negative Control; L.Ladder 
Fig. (7) showed that Sr26\#43, which originally introgressed into the distal region of the long arm of hexaploid wheat chromosome $6 \mathrm{~A}, \mathrm{Sr} 26$ is one the few known major resistance genes effective against the Sr31-virulent race Ug99 (TTKSK) and its Sr24virulent derivative (TTKST). A combination (i.e. multiplexing) of two dominant PCR markers in repulsion phase provides a diagnostic co-dominant marker for Sr26: Sr26\#43, a dominant marker for the presence of $\operatorname{Sr} 26$ and amplifies band fragment of $(\mathbf{2 0 7}$ bp) Liu et al. (2010).

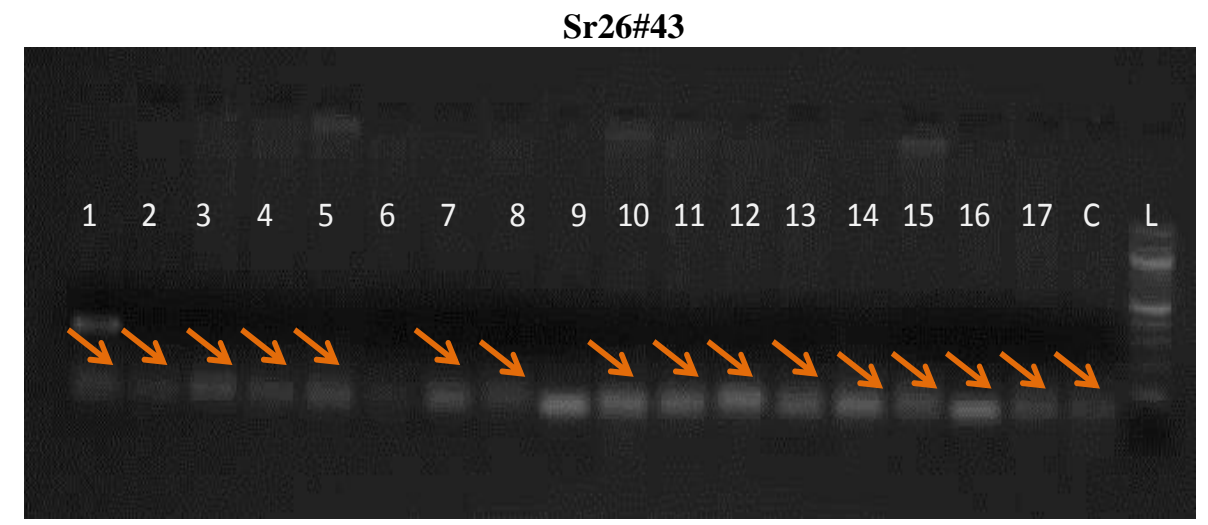

Figure (7): Sr 26\#43 genes in seventeen cultivars 1. Misr 1; 2. Giza 168; 3. Gemmeiza 10; 4. Nobaria 1; 5. Sahel 1; 6. Sids 13; 7. Sids 4; 8. Sakha 94; 9. Gemmeiza 11; 10. Giza 171; 11. Gemmeiza 9; 12. Sids 1; 13. Bani Suef 5; 14. Bani Sueif 6; 15. Sohag 3; 16. DH 4; 17. DH 5 ; +C. Positive Control; -C. Negative Control; L.Ladder

Sr25 was detected in (Fig 8), which was transferred into wheat from Thinopyrum ponticum (Barkworth and Dewey) and it is effective to $U g 99$. $\mathrm{Sr} 25$ and the linked leaf rust resistance gene $\operatorname{Lr} 19$ were

translocated onto the long arm of wheat chromosomes 7D (1) and 7A (2). The dominant marker, Gb, amplifies band of $130 \mathrm{bp}$ for this gene lui et al. (2010).

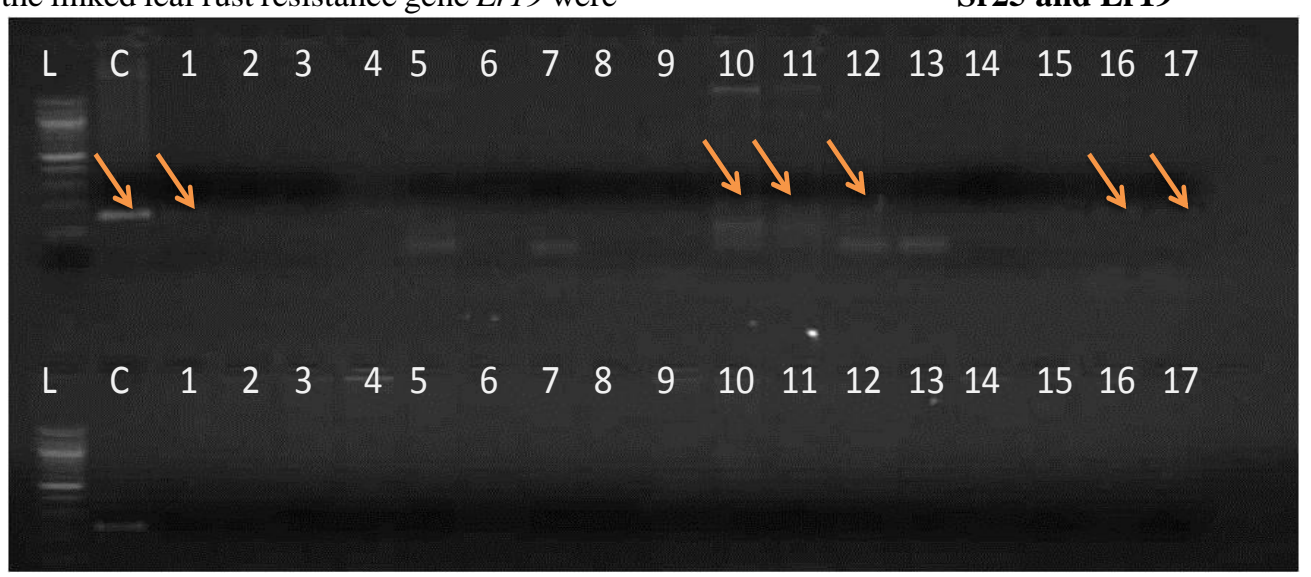

Figure (8): Sr 25\#Lr 19 genes in seventeen cultivars 1. Misr 1; 2. Giza 168; 3. Gemmeiza 10; 4. Nobaria 1; 5. Sahel 1; 6. Sids 13; 7. Sids 4; 8. Sakha 94; 9. Gemmeiza 11; 10. Giza 171; 11. Gemmeiza 9; 12. Sids 1; 13. Bani Suef 5; 14. Bani Suef 6; 15. Sohag 3; 16. DH 4; 17. DH 5 ; +C. Positive Control; -C. Negative Control; L.Ladder

Table (5) presents the results of eight SSR markers linked to rust resistance as $1=$ gene present and $0=$ gene absent. $\operatorname{Yr} 10$ positive molecular marker Linked to $\operatorname{Yr} 10$ gene detected in Misr1, Sids 1 and DH\#3. Yr 15 gene was found in Misr 1, Giza 168, Sahel 1, Sids 4, Sids 1, Bani Suef 5, Bani Seif 6, DH\#2 and DH\#3. $\operatorname{Lr} 34$ leaf rust gene was found in Sids 13, Sakha 94 and DH\# 3, while $\operatorname{Lr} 47$ gene was detected in Misr 1, DH\# 2 and DH\#3, but $\operatorname{Lr} 19$ was not detected in any genotypes. Sr 2 durable resistant stem rust gene detected in all genotypes expect Sids 1, moreover $\mathrm{Sr} 26 \# 43$ detected in all cultivars expect Sids 4 cultivar. $\operatorname{Sr} 12$ gene was detected in Misr 1, Giza 171, Gemmeiza 9 and DH\# 3. All cultivars free from $\operatorname{Sr} 24$, while $\operatorname{Sr} 25$ resistance stem rust gene was detected in Misr 1, Giza 171 and DH\# 3 resistance cultivars. 
Table 5. Resistant (one) and susceptible (zero) SSR primers fragments for leaf, yellow and steam rust genes in seventeen bread and durum wheat.

\begin{tabular}{|c|c|c|c|c|c|c|c|c|c|c|}
\hline \multirow[b]{2}{*}{ Cultivars } & \multicolumn{10}{|c|}{ Genes } \\
\hline & $\operatorname{Lr} 19$ & $\begin{array}{l}\mathrm{Lr} \\
34\end{array}$ & $\begin{array}{l}\mathrm{Lr} \\
47\end{array}$ & $\begin{array}{l}Y r \\
10\end{array}$ & $\begin{array}{l}Y r \\
15\end{array}$ & $\begin{array}{c}S r \\
2\end{array}$ & $\begin{array}{l}\mathrm{Sr} \\
12\end{array}$ & $\begin{array}{l}S r \\
24\end{array}$ & $\begin{array}{c}\text { Sr25\# } \\
\text { Lr19 }\end{array}$ & $\begin{array}{c}\text { Sr26\# } \\
43\end{array}$ \\
\hline Misr1 & 0 & 0 & 1 & 1 & 1 & 1 & 1 & 0 & 1 & 1 \\
\hline Giza168 & 0 & 0 & 0 & 0 & 1 & 1 & 0 & 0 & 0 & 1 \\
\hline Gem 10 & 0 & 0 & 0 & 0 & 0 & 1 & 0 & 0 & 0 & 1 \\
\hline Nubaria 1 & 0 & 0 & 0 & 0 & 0 & 1 & 0 & 0 & 0 & 1 \\
\hline Sahel 1 & 0 & 0 & 0 & 0 & 1 & 1 & 0 & 0 & 0 & 1 \\
\hline Sids 13 & 0 & 1 & 0 & 0 & 0 & 1 & 0 & 0 & 0 & 0 \\
\hline Sids 4 & 0 & 0 & 0 & 0 & 1 & 1 & 0 & 0 & 0 & 1 \\
\hline Sakha 94 & 0 & 1 & 0 & 0 & 0 & 1 & 0 & 0 & 0 & 1 \\
\hline Gemmeiza 11 & 0 & 0 & 0 & 0 & 0 & 1 & 0 & 0 & 0 & 1 \\
\hline Giza 171 & 0 & 0 & 0 & 0 & 0 & 1 & 1 & 0 & 1 & 1 \\
\hline Gemmeiza 9 & 0 & 0 & 0 & 0 & 0 & 1 & 1 & 0 & 0 & 1 \\
\hline Sids 1 & 0 & 0 & 0 & 1 & 1 & 0 & 0 & 0 & 0 & 1 \\
\hline Beni Suef 5 & 0 & 0 & 0 & 0 & 1 & 1 & 0 & 0 & 0 & 1 \\
\hline Beni Suef 6 & 0 & 0 & 0 & 0 & 1 & 1 & 0 & 0 & 0 & 1 \\
\hline Sohag 3 & 0 & 0 & 0 & 0 & 0 & 1 & 0 & 0 & 0 & 1 \\
\hline $\mathrm{DH} 2$ & 0 & 0 & 1 & 0 & 1 & 1 & 0 & 0 & 0 & 1 \\
\hline DH\#3 & 0 & 1 & 1 & 1 & 1 & 1 & 1 & 0 & 1 & 1 \\
\hline
\end{tabular}

$(1)=$ resistant gene and $(0)=$ No Gene in genotype

In order to detect more than one gene in any variety for rust resistance, we need to identify combinations of resistance genes for durable resistance to make slow rusting (Savitha et al. (2016). Seven rust genes were detected in Misr 1 resistant varietys and eight resistance genes were found in promising line DH\# 3, which caused resistant to the three types of rust. So, Misr 1 and DH\# 3 promising bread wheat high yielding abilils and resistant to rust diseases can be used in pyramiding resistance gene in breeding program, as pre breeding in hybridization program.

\section{References}

Agricultural Economic and Statistics Department, Ministry of Agriculture, 2017.

Chen X M., Line RF and Leung H (1995). Virulence and polymorphic DNA relationships of Puccinia striiformis f. sp. Hordes to other rusts. Phytopathology. 85:1335-42.

Chhuneja, P., Vikal, Y., Kaur, S., Singh, R., Juneja, S., Bains, N. S., Berry, O., Sharma,A., Gupta, S. K., Charpe, A., Prabhu, K. V. and Dhaliwal, H. S. (2011). Marker-Assisted Pyramiding of Leaf Rust Resistance Genes Lr24 and Lr28 in Wheat (Triticum aestivum L). Indian J. Agric. Sci.,81(3): 214-218.

Dellaporta, S. L., Wood, J. and Hicks, J. B. (1983). A Plant DNA Mini-Preparation: Version II. Plant Molec. Biol. Rep., 1: 19- 21.

Helguera M., I. A. Khan and J. , Dubcovsky (2000). Development of PCR markers for the wheat leaf rust resistance gene Lr47. Theoretical and Applied Genetics 100:1137-1143.
Liu S, Yu L-X, Singh RP, Jin Y, Sorrells ME and Anderson JA (2010). Diagnostic and codominant PCR markers for wheat stem rust resistance genes $S r 25$ and $S r 26$. Theoretical and Applied Genetics, 120:691-697.

Mahmoud, A. M. and T. A. Ahmed (2005). Variability, regression and cluster analysis in bread wheat (Triticum aestivum L.). Assiut J. Agric. Sci. 36(2): 41-56

Marsalis, M. A. and Goldberg, N. P. (2006). Leaf, Stem and Stripe Rust Diseases of Wheat. New Mexico State University Guide A-415. (http://www.cahe.nmsu.edu).

Metzger R. J., and B. A. Silbaugh (1970)inheryance of Resistance to stripe rust band its Association with Brown Glume Color in Triticum aestivum L. Crops Science, (10):567-568.

Peltonen-Sainio, P., A. Kangas, S. YrjŐ and L. Jauhiainen (2007). Grain number dominates grain weight in temperate cereal yield determination: evidence based on 30 years of multi-location traits. Field Crops Res.100:179188.

Qi A, Zhang P, Xia X, He Z, Huerta-Espino J, Li Z and Liu $D$ (2015). Molecular mapping and markers for leaf rust resistance gene $\mathrm{Lr} 24$ in CIMMYT wheat line 19HRWSN-122. Euphytica, 206:57-66

Revathi, P. S., Tomar, M., Vinod, S. and Singh, N. K. (2010). Marker Assisted Gene Pyramiding of Leaf Rust Resistance Genes Lr24, Lr28 along with Stripe Rust Resistance Gene $\operatorname{Yrl5}$ in Wheat (Triticum aestivum L.). Indian J. Genet., 70(40): 349-354. 
Roelfs, A. P. (1988). Resistance to Leaf and Stem Rust in Wheat. In: "Breeding Strategies for Resistance to the Rusts of Wheat", (Eds.): Simmonds, N. W. and Rajaram, S.. CIMMYT, Mexico DF, 10-22.

Roelfs A.P.(1989). Epidemiology of the cereal rusts in North America. Can J Plant Pathol. ;11:86-90.

Roelfs, A.P., R.P. Singh, and E.E. Saari (1992). Rust Diseases of Wheat: Concepts and methods of disease management. Mexico, D.F.: CIMMYT. 81 pages.

Rouse MN1, Talbert LE, Singh D and Sherman JD ( 2014). Complementary epistasis involving Sr12 explains adult plant resistance to stem rust in Thatcher wheat (Triticum aestivum L.). Theor Appl Genet. 127(7):1549-59.
Savitha, B. S., S. A. Desai1, S. S. Biradar1, R. Naik1, and H. C. Lohithaswa (20016). Identification of SSR Marker Linked to Leaf Rust Resistant Gene Lr24 and Marker Assisted Transfer of Leaf Rust Resistance Genes into Bread Wheat. J. Agr. Sci. Tech. (18): 545-552

Singh, N. K. (2010). Marker Assisted Gene Pyramiding of Leaf Rust Resistance Genes Lr24, Lr28 along with Stripe Rust Resistance Gene Yr15 in Wheat (Triticum aestivum L.). Indian J. Genet., 70(40): 349-354.

Singh RP and Huerta-Esbino J (2003). Effect of leaf rust resistance gene $\mathrm{Lr} 34$ on components of slow rusting at seven growth stages in wheat. Euphytica, 129:371-376.

\title{
التعرف على جينات المقاومة الخاصة بصدأ الأولق والمخطط والساق فى بعض أصناف قـح الخبز والمكرونة عالية
}

\author{
المحصول
}

\author{
هلى مصطفى مصطفى الغرياوى و خالا ابراهيم محمد جاد \\ مركز البحوث الزراعية - معهد بحوث المحاصيل الحقلية - قسم بحوث القمح - محطة بحوث الجيزة.
}

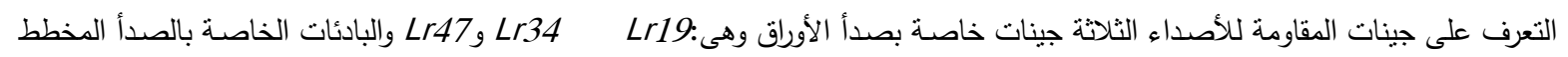

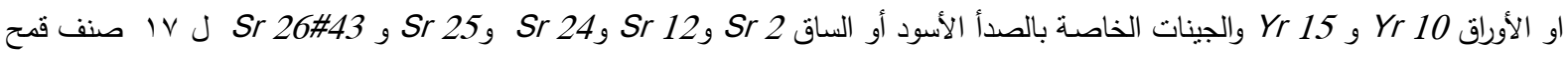

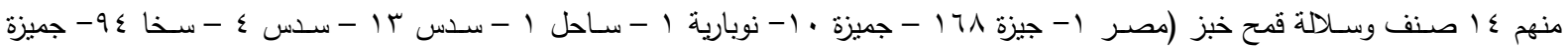

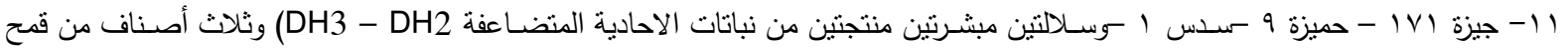
المكرونة (بنى سـويف ه - وبنى سـويف 1 - سـوهاج ب) بواسطة المعلمات الجزيئية باسـتخدام بادئات متخصسصـة بتكنيك SSR.

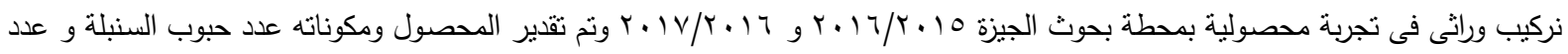

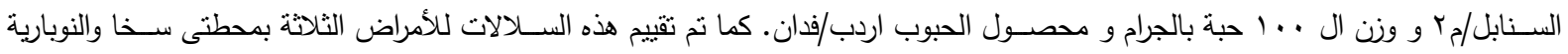

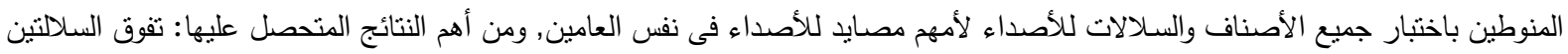

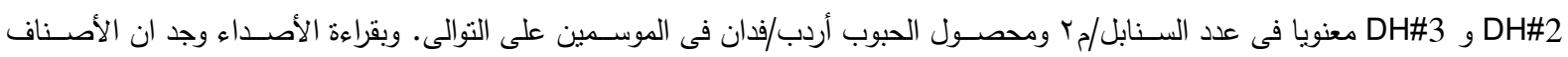

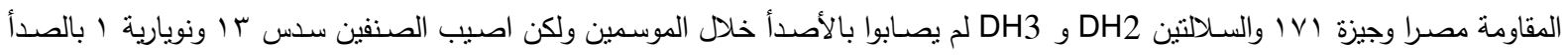
الأصفر 5MS و 10MS لصدأ الأوراق. ولم ينم الاصـابة بالصدا الأسود فى جميع الأصناف محل الدراسـة. بالكثف عن جينات المقاومة للصدأ

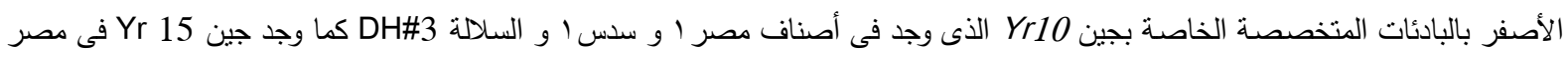

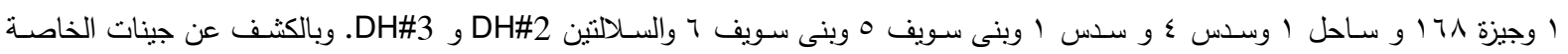

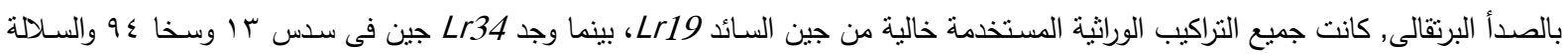
DH3, وكذلك وجد جين Lr47 فى مصـر ا والسـلالتين DH\#2 و DH\#3. وبالكثـف على جينات المقاومة للصـــأ الأسـود وجد أن جين المقاوم Sr2 المســب التأخير بالإصــابة فى الأصــناف المصــرية موجود في جميع التراكيب الوراثية المســتخدمة معدا ســـس الوكذلك جينى المقاومة

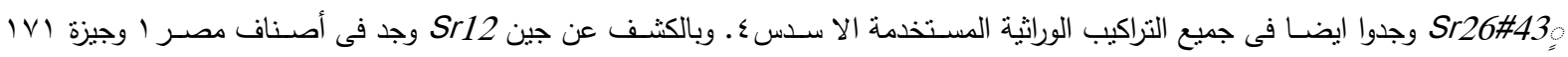

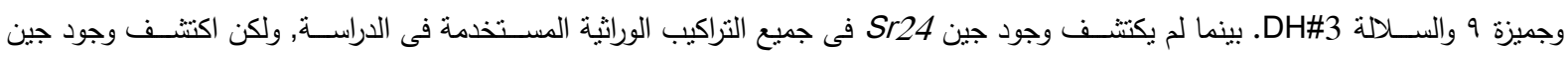

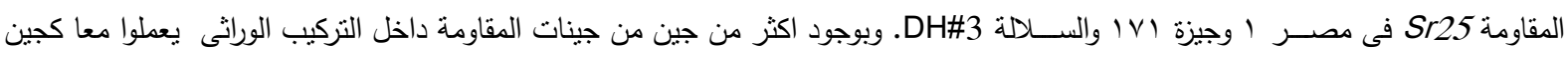

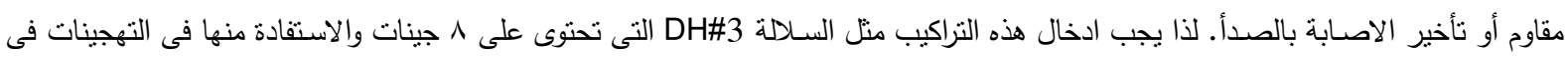
برنامج التربية مع الأصناف التى لا تحنوى على تلك الجينات والعمل على التربية الهرمية لجينات المقاومة للأصداء. 